\title{
Dry Media Synthesis of Novel Pyrrolo-pyrimidines
}

\author{
A. D. Mishra" \\ Department of Chemistry, P. N. Campus, Tribhuvan University, Pokhara, Nepal. \\ e-mail:mishraad05@hotmail.com
}

\begin{abstract}
A series of new 2-thioxo-3,7-disubstituted-5,6-diphenylpyrrolo[2,3-d]pyrimidin-4(1H) -ones have been synthesized by the condensation of 2-amino3-ethylcarboxylate-4,5-diphenyl pyrroles with mono-substituted arylthioureas in dry media under microwave irradiations. All the synthesized compounds were screened for their antifungal and antibacterial activities and found to possess mild to moderate antimicrobial activities.
\end{abstract}

Keywords: Thioureas, Pyrrolo-pyrimidines, Microwave irradiation, Antimicrobial activities.

\section{Introduction}

Pyrrolo-pyrimidines have been introduced as an important class of chemotherapeutics since they are structurally and chemically related to naturally occurring nucleosides and some antibiotics ${ }^{1,2}$. These compounds have been intensively investigated as antitumor, antiallergic, antiviral and anti inflammatory agents $\mathrm{s}^{3-6}$.

Several conventional and non-conventional methods have been reported ${ }^{7-10}$ for the synthesis of pyrrolo[2,3-d]pyrimidines earlier. But these methods are associated with many drawbacks like, multistep synthetic route, longer reaction time with drastic conditions, low yield and use of expensive and hazardous chemicals. These drawbacks have been eliminated by synthesizing the title compounds under microwave irradiations, using dry media. Microwave assisted organic synthesis proceeds with facile reactions to provide high yield with less reaction time ${ }^{11-14}$ and avoids the usage of excess solvents and harmful acids and bases that are generally used in the catalysis of the reactions ${ }^{15-18}$. Solution phase microwave organic reactions have some limitations as superheating of the solvents may result explosion ${ }^{19,20}$. Reactions can be carried out at ambient pressure in open vessels under solid supports by using domestic microwave ovens ${ }^{21-24}$. Use of solid acid and base catalysts reduce the amount of toxic wastes and byproducts arising from chemical processes ${ }^{25}$.

Diverse chemotherapeutic interest of this class of compounds is major cause of synthesis of these novel 2-thioxo-pyrrolo[2,3-d]pyrimidin-4(1H)-ones in dry media under microwave irradiations by the condensation of 2-amino-pyrroles and mono-substituted thioureas.

* Corresponding author 


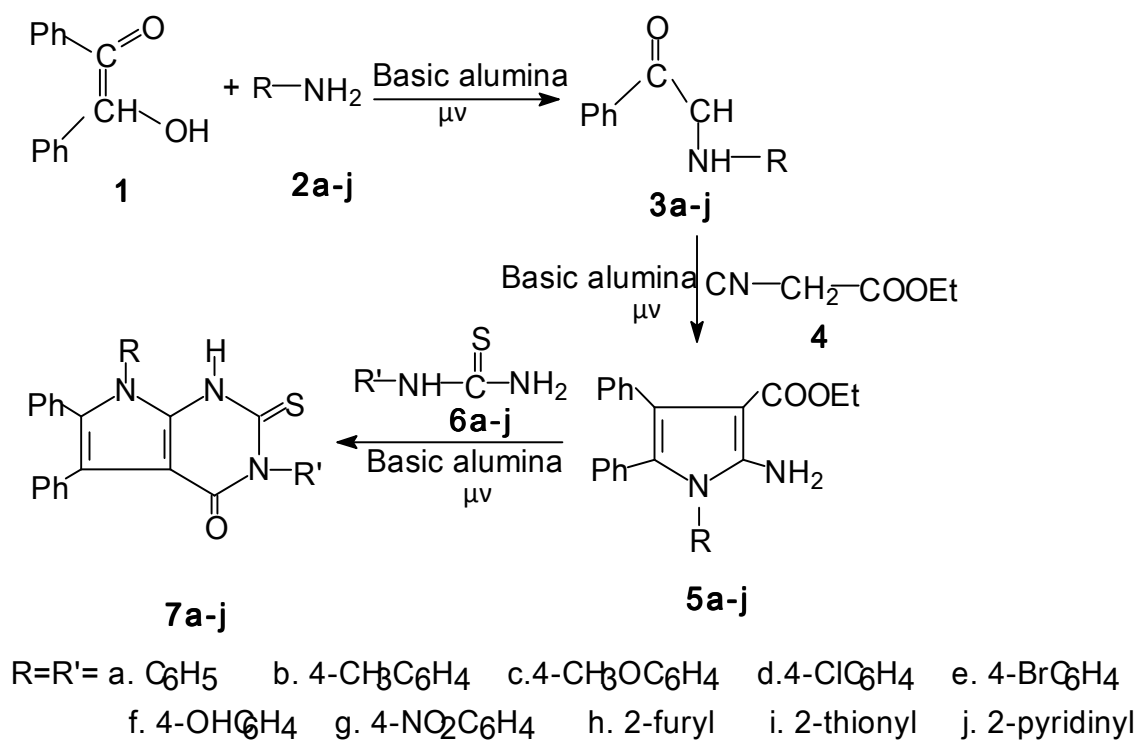

\section{Scheme 1}

\section{Experimental Methods}

Microwave irradiations were carried out in Kenstar Microwave Oven, Model No. OM9925E (2450 MHz, $800 \mathrm{~W}$ ) and IR spectra were recorded on FT NMR Hitachi R-600 $(60 \mathrm{MHz})$ instrument. Elemental analyses were performed by means of Heraeus CHN-Rapid Analyzer. Temperature of reaction mixtures were measured on AZ, Mini Gun Type NonContact IR thermometer, Model No. 8868. All the melting points were determined on a Thomas Hoover melting point apparatus and are uncorrected. Chemical shift $(\delta)$ for ${ }^{1} \mathrm{H}$ NMR is given in ppm relative to internal reference, tetramethylsilane (TMS) and IR frequency $(v)$ in $\mathrm{cm}^{-1}$. The purity of the compounds was checked on aluminium plates coated with silica gel (Merk).

General procedures for the synthesis of 2-amino-2-phenyl-acetophenones (3a-j) were prepared by adopting literature method ${ }^{26-28}$ modified with microwave irradiations. Again, the procedures for the Synthesis of 2-amino-3-ethylcarboxylate-4,5-diphenylpyrroles (5a-j) were followed as: equimolar amounts $(0.01$ mole) of 2-amino-2-phenylacetophenones (3a-j) and cyano-ethyl acetate (4) were dissolved in $10 \mathrm{ml}$ of EtOH and the resulting solution was adsorbed over $20 \mathrm{~g}$ basic alumina or montmorillonite (K10) clay in a small beaker. The beaker containing reaction mixture was then kept in microwave oven in an alumina bath and irradiated for 6-7 minutes intermittently. TLC was monitored at an interval of 30 seconds. The product 5a-j was extracted with $\mathrm{EtOH}(4 \mathrm{x} 10 \mathrm{ml})$ and obtained in solid state on recovering the solvent by distillation under reduced pressure. Furthermore, synthesis of 2 thioxo-3,7-disubstituted-5,6-diphenyl-pyrrolo[2,3-d]pyrimidin-4(1H)-ones(7a-j) was carried out using conventional and microwave methods. 
Conventional Method: 0.01 mole of 2-amino-3-ethylcarboxylate-4,5-diphenyl-pyrrole $(\mathbf{5 a - j})$ and thiourea $(\mathbf{6 a - j})$ were dissolved in $20 \mathrm{ml}$ of DMF and the solution was refluxed for 12 hours. On completion of the reaction as monitored by TLC examination, the reaction mixture was plunged into ice-cold water and kept standing over night. The solid obtained after filtration was washed, dried and recrystallized from $\mathrm{MeOH}$ to give 7a-j.

Microwave Method: 0.01 mole of 2-amino-3-ethylcarboxylate-4,5-diphenyl-pyrrole (5a-j) and thiourea (6a-j) were dissolved in $10 \mathrm{ml}$ of EtOH and the resulting solution was adsorbed over $20 \mathrm{~g}$ of basic alumina or montmorillonite-K10 clay in a small beaker. The reaction mixture was dried in air and irradiated in microwave oven for 7-8 minutes. TLC was monitored at an interval of 30 seconds. The product (7a-j) was extracted with EtOH (4 $\mathrm{x} 10 \mathrm{ml}$ ) and obtained in solid state after recovering EtOH by distillation under reduced pressure. The product was recrystallized from $\mathrm{MeOH}$.

\section{Results and Discussion}

Benzoin (1) was treated with primary amine (2a-j) to furnish the intermediate product (3a-j), which was then cyclised with cyanoethylacetate (4) to obtain substituted pyrrole (5aj). This precursor was condensed with mono-substituted thiourea (6a-j) and pyrrolo[2,3d]pyrimidine (7a-j) was obtained. The reaction took 8-9 minutes with 80-92\% yield in microwave irradiations whereas it took 11-12 hours with 60-72\% yield in conventional method (Table 1). Use of montmorillonite-K10 clay instead of basic alumina, reduces reaction time accompanied with low product. Similarly the use of only alcohols and DMF in place of other expensive and hazardous organic solvents made the adopted procedure more ecofriendly. These observations clearly show the superiority of microwave chemical reactions over conventional reactions in terms of reaction time and yield.

Table 1: Comparison of reaction times and yields for the transformations $5 a-j \rightarrow 7 a-j *$

\begin{tabular}{|c|c|c|c|c|c|}
\hline & \multirow{2}{*}{$\begin{array}{c}\text { M. P. } \\
\left({ }^{\circ} \mathrm{C}\right)\end{array}$} & \multicolumn{2}{|c|}{ Reaction times } & \multicolumn{2}{c|}{ Yields (\%) } \\
\cline { 3 - 6 } & & $\begin{array}{c}\text { Microwave } \\
\text { reaction (min) }\end{array}$ & $\begin{array}{c}\text { Conventional } \\
\text { reaction (h) }\end{array}$ & $\begin{array}{c}\text { Microwave } \\
\text { reaction }\end{array}$ & $\begin{array}{c}\text { Conventional } \\
\text { reaction }\end{array}$ \\
\hline $7 \mathrm{a}$ & 110 & 9.0 & 12.0 & 80 & 62 \\
$7 \mathrm{~b}$ & 117 & 8.5 & 11.0 & 87 & 65 \\
$7 \mathrm{c}$ & 143 & 8.0 & 11.0 & 91 & 68 \\
$7 \mathrm{~d}$ & 168 & 8.0 & 11.5 & 90 & 65 \\
$7 \mathrm{e}$ & 156 & 8.5 & 12.0 & 85 & 67 \\
$7 \mathrm{f}$ & 137 & 9.0 & 12.0 & 82 & 60 \\
$7 \mathrm{~g}$ & 183 & 8.0 & 11.0 & 87 & 70 \\
$7 \mathrm{~h}$ & 149 & 9.0 & 12.0 & 86 & 67 \\
$7 \mathrm{i}$ & 128 & 8.5 & 11.5 & 92 & 72 \\
$7 \mathrm{j}$ & 162 & 9.0 & 12.0 & 80 & 60 \\
\hline
\end{tabular}

$*$ all the compounds showed satisfactory $C, H$ and $N$ analysis within the variation $\pm 0.04 \%$.

The structures of the synthesized pyrrolo[2,3-d]pyrimidines (7a-j) were confirmed from spectral and microanalytical data (Table 2). IR band at $1220-1230 \mathrm{~cm}^{-1}$ due to thioxo 
group whereas the band at $1722-1732 \mathrm{~cm}^{-1}$ due to keto group confirmed the formation of product. Further the IR absorption band at $3510-3518 \mathrm{~cm}^{-1}$ confirmed the presence of secondary amino group $(=\mathrm{N}-\mathrm{H})$ in the synthesized pyrrolo[2,3-d]pyrimidines. All the aromatic protons including that of furyl, thionyl and pyridinyl substitutions in the pyrrolopyrimidines appear at 6.3-8.2 ppm in ${ }^{1} \mathrm{H}$ NMR analysis. A broad singlet is observed at 11.6$11.8 \mathrm{ppm}$ due to $\mathrm{NH}$ proton in the pyrimidine ring of pyrrolo[2,3-d]pyrimidines.

Table 2: Spectroscopic data of the compounds 7a-j.

\begin{tabular}{|c|}
\hline $\begin{array}{l}\text { 2-thioxo-3,5,6.7-tetraphenyl-pyrrolo[2,3-d]pyrimidin-4(1H)-one } \\
\left(\mathbf{7} \mathbf{a} ; \mathbf{C}_{\mathbf{3 0}} \mathbf{H}_{\mathbf{2 I}} \mathbf{N}_{\mathbf{3}} \mathbf{0 S}\right) \text { : IR(KBr): } 1221(\mathrm{C}=\mathrm{S}), 1727(\mathrm{C}=0), 3412(\mathrm{~N}-\mathrm{H}) \mathrm{cm}^{-1} ;{ }^{1} \mathrm{H} \mathrm{NMR}_{\left(\mathrm{CDCl}_{3}+\right.} \\
\left.\text { DMSO-d }{ }_{6}, \delta, 60 \mathrm{MHz}\right): 7.1-7.3(\mathrm{~m}, 20 \mathrm{H}, \mathrm{Ar}-\mathrm{H}), 11.7(\mathrm{brs}, 1 \mathrm{H}, \mathrm{NH}) \mathrm{ppm} .\end{array}$ \\
\hline $\begin{array}{l}\text { 2-thioxo-3,7-di(4'-methylphenyl)-5,6-diphenyl-pyrrolo[2,3-d]pyrimidin-4(1H)-one } \\
\left(\mathbf{7 b}_{\mathbf{b}} \mathbf{C}_{\mathbf{3 2}} \mathbf{H}_{\mathbf{2 5}} \mathbf{N}_{\mathbf{3}} \mathbf{0 S}\right) \text { : IR }(\mathrm{KBr}): 1220(\mathrm{C}=\mathrm{S}), 1724(\mathrm{C}=0), 3413(\mathrm{~N}-\mathrm{H}) \mathrm{cm}^{-1} ;{ }^{1} \mathrm{H} \mathrm{NMR}\left(\mathrm{CDCI}_{3}+\right. \\
\left.\text { DMSO-d }_{6}, \delta, 60 \mathrm{MHz}\right): 2.3\left(\mathrm{~s}, 6 \mathrm{H}, 2 \times \mathrm{CH}_{3}\right), 7.1-7.3(\mathrm{~m}, 18 \mathrm{H}, \mathrm{Ar}-\mathrm{H}), 11.6(\mathrm{brs}, \mathrm{I} \mathrm{H}, \mathrm{NH}) \mathrm{ppm} .\end{array}$ \\
\hline $\begin{array}{l}\text { 2-thioxo-3,7-di(4'-methoxyphenyl)-5,6-diphenyl-pyrrolo[2,3-d]pyrimidin-4(1H)-one } \\
\left(\mathbf{7 c} ; \mathbf{C}_{\mathbf{3 2}} \mathbf{H}_{\mathbf{2 5}} \mathbf{N}_{\mathbf{3}} \mathbf{0}_{\mathbf{3}} \mathbf{S}\right) \text { : IR(KBr): } 1223(\mathrm{C}=\mathrm{S}), 1726(\mathrm{C}=0), 3415(\mathrm{~N}-\mathrm{H}) \mathrm{cm}^{-1} ;{ }^{1} \mathrm{H} \mathrm{NMR}\left(\mathrm{CDCl}_{3}+\right. \\
\left.\text { DMSO-d }{ }_{6}, \delta, 60 \mathrm{MHz}\right): 4.0\left(\mathrm{~s}, 6 \mathrm{H}, 2 \times \mathrm{OCH}_{3}\right), 7.0-7.4(\mathrm{~m}, 18 \mathrm{H}, \mathrm{Ar}-\mathrm{H}), 11.7(\mathrm{brs}, 1 \mathrm{H}, \mathrm{NH}) \mathrm{ppm} .\end{array}$ \\
\hline $\begin{array}{l}\text { 2-tioxo-3,7-di(4'-chlorophenyl)-5,6-diphenyl-pyrrolo[2,3-d]pyrimidin-4(1H-one } \\
\left(\mathbf{7 d} ; \mathbf{C}_{\mathbf{3 0}} \mathbf{H}_{\mathbf{1 9}} \mathbf{N}_{\mathbf{3}} \mathbf{O S C l}_{\mathbf{2}}\right) \text { : IR(KBr): } 1225(\mathrm{C}=\mathrm{S}), 1727(\mathrm{C}=0), 3412(\mathrm{~N}-\mathrm{H}) \mathrm{cm}^{-1} ;{ }^{1} \mathrm{H} \mathrm{NMR}\left(\mathrm{CDCl}_{3}\right. \\
\left.+ \text { DMSO-d }{ }_{6}, \delta, 60 \mathrm{MHz}\right): 7.2-7.5(\mathrm{~m}, 18 \mathrm{H}, \mathrm{Ar}-\mathrm{H}), 11.8(\mathrm{brs}, 1 \mathrm{H}, \mathrm{NH}) \mathrm{ppm} .\end{array}$ \\
\hline $\begin{array}{l}\text { 2-thioxo-3,7-di(4'-Bromophenyl)-5,6-diphenyl-pyrrolo[2,3-d]pyrimidin-4(IH)-one } \\
\left(\mathbf{7 e}_{\mathbf{e}} \mathbf{C}_{\mathbf{3 0}} \mathbf{H}_{\mathbf{1 9}} \mathbf{N}_{\mathbf{3}} \mathbf{O S B r}_{\mathbf{2}}\right) \text { : IR(KBr): } 1221(\mathrm{C}=\mathrm{S}), 1725(\mathrm{C}=\mathrm{O}), 3410(\mathrm{~N}-\mathrm{H}) \mathrm{cm}^{-1} ;{ }^{1} \mathrm{H} \mathrm{NMR}_{(\mathrm{CDCl}} \mathrm{CD}_{3} \\
\left.\text { + DMSO-d }{ }_{6}, \delta, 60 \mathrm{MHz}\right): 7.2-7.5(\mathrm{~m}, 18 \mathrm{H}, \mathrm{Ar}-\mathrm{H}), 11.7(\mathrm{brs}, 1 \mathrm{H}, \mathrm{NH}) \mathrm{ppm} .\end{array}$ \\
\hline 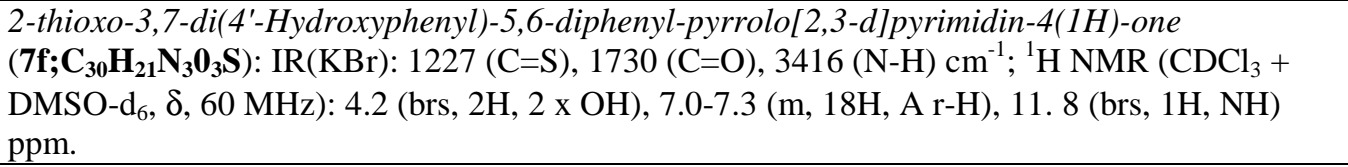 \\
\hline $\begin{array}{l}\text { 2-thioxo-3,7-di(4'-Nitrophenyl)-5,6-diphenyl-pyrrolo[2,3-d]pyrimidin-4(1H)-one } \\
\left(\mathbf{7 g} ; \mathbf{C}_{\mathbf{3 0}} \mathbf{H}_{\mathbf{1 9}} \mathbf{N}_{\mathbf{5}} \mathbf{0}_{5} \mathbf{S}\right) \text { : IR(KBr): } 1230(\mathrm{C}=\mathrm{S}), 1732(\mathrm{C}=\mathrm{O}), 3418(\mathrm{~N}-\mathrm{H}) \mathrm{cm}^{-1} ;{ }^{1} \mathrm{H} \mathrm{NMR}\left(\mathrm{CDCl}_{3}+\right. \\
\left.\text { DMSO-d }{ }_{6}, \delta, 60 \mathrm{MHz}\right): 7.2-7.8(\mathrm{~m}, 18 \mathrm{H}, \mathrm{Ar}-\mathrm{H}), 11.8(\mathrm{brs}, 1 \mathrm{H}, \mathrm{NH}) \mathrm{ppm} .\end{array}$ \\
\hline $\begin{array}{l}\text { 2-thioxo-3,7-di(2'-furyl)-5,6-diphenyl-pyrrolo[2,3-d]pyrimidin-4(1H)-one }\left(\mathbf{7 h} ; \mathbf{C}_{\mathbf{2 6}} \mathbf{H}_{\mathbf{1 7}} \mathbf{N}_{\mathbf{3}} \mathbf{0}_{\mathbf{3}} \mathbf{S}\right) \text { : } \\
\text { IR(KBr): } 1225(\mathrm{C}=\mathrm{S}), 1731(\mathrm{C}=\mathrm{O}), 3417(\mathrm{~N}-\mathrm{H}) \mathrm{cm}^{-1} ;{ }^{1} \mathrm{H} \mathrm{NMR}\left(\mathrm{CDCl}_{3}+\mathrm{DMSO}_{6}, \delta, 60\right. \\
\mathrm{MHz}): 6.3-7.4(\mathrm{~m}, 16 \mathrm{H}, \mathrm{Ar}-\mathrm{H}), 11.7(\mathrm{brs}, 1 \mathrm{H}, \mathrm{NH}) \mathrm{ppm} \text {. }\end{array}$ \\
\hline $\begin{array}{l}\text { 2-thioxo-3,7-di(2'-thionyl)-5,6-diphenyl-pyrrolo[2,3-d]pyrimidin-4(1H)-one } \\
\left(\mathbf{7 i} ; \mathbf{C}_{\mathbf{2 6}} \mathbf{H}_{\mathbf{1 7}} \mathbf{N}_{\mathbf{3}} \mathbf{O S}_{\mathbf{3}}\right) \text { : } \mathrm{IR}(\mathrm{KBr}): 1225(\mathrm{C}=\mathrm{S}), 1722(\mathrm{C}=\mathrm{O}), 3410(\mathrm{~N}-\mathrm{H}) \mathrm{cm}^{-1} ;{ }^{1} \mathrm{H} \mathrm{NMR}\left(\mathrm{CDCl}_{3}+\right. \\
\left.\text { DMSO-d }{ }_{6}, \delta, 60 \mathrm{MHz}\right): 7.1-7.4(\mathrm{~m}, 16 \mathrm{H}, \mathrm{Ar}-\mathrm{H}), 11.6(\mathrm{brs}, 1 \mathrm{H}, \mathrm{NH}) \mathrm{ppm} .\end{array}$ \\
\hline $\begin{array}{l}\text { 2-thioxo-3,7-di(2'-pyridinyl)-5,6-diphenyl-pyrrolo[2,3-d]pyrimidin-4(1H)-one } \\
\left(\mathbf{7} \mathbf{j} ; \mathbf{C}_{\mathbf{2 8}} \mathbf{H}_{\mathbf{1 9}} \mathbf{N}_{\mathbf{5}} \mathbf{0 S}\right) \text { : IR }(\mathrm{KBr}): 1220(\mathrm{C}=\mathrm{S}), 1724(\mathrm{C}=\mathrm{O}), 3415(\mathrm{~N}-\mathrm{H}) \mathrm{cm}^{-1} ;{ }^{1} \mathrm{H} \mathrm{NMR}\left(\mathrm{CDCl}_{3}+\right. \\
\left.\text { DMSO-d }{ }_{6}, \delta, 60 \mathrm{MHz}\right): 6.9-8.2(\mathrm{~m}, 18 \mathrm{H}, \mathrm{Ar}-\mathrm{H}), 11.7(\mathrm{brs}, 1 \mathrm{H}, \mathrm{NH}) \mathrm{ppm} .\end{array}$ \\
\hline
\end{tabular}

Pyrrolopyrimidines (7a-j) were screened for their in vitro antifungal activities against Aspergillus Niger and Aspergillus flavus by the paper disc diffusion method ${ }^{29,30}$ and in vitro antibacterial activities against E. coli, Rhizobium japonicum, Enterobactor aerogenes, Burkholderia cepacia and Bacillus mojavencis by the cup diffusion method ${ }^{31}$. Salicyclic acid and oxytetracycline were used as reference drugs in antifungal and antibacterial activities respectively. The test compounds were dissolved in DMF at a concentration of 50 
$\mu \mathrm{g} / \mathrm{ml}$. The zone of inhibition was measured in millimeters. The compounds (7a, $\mathbf{7 b}, \mathbf{7 d}, \mathbf{7 e}$ and 7i) exhibited promising antifungal and antibacterial activities (Table 3).

Table 3: In vitro antibacterial and antifungal activities of compounds, 7a-j.

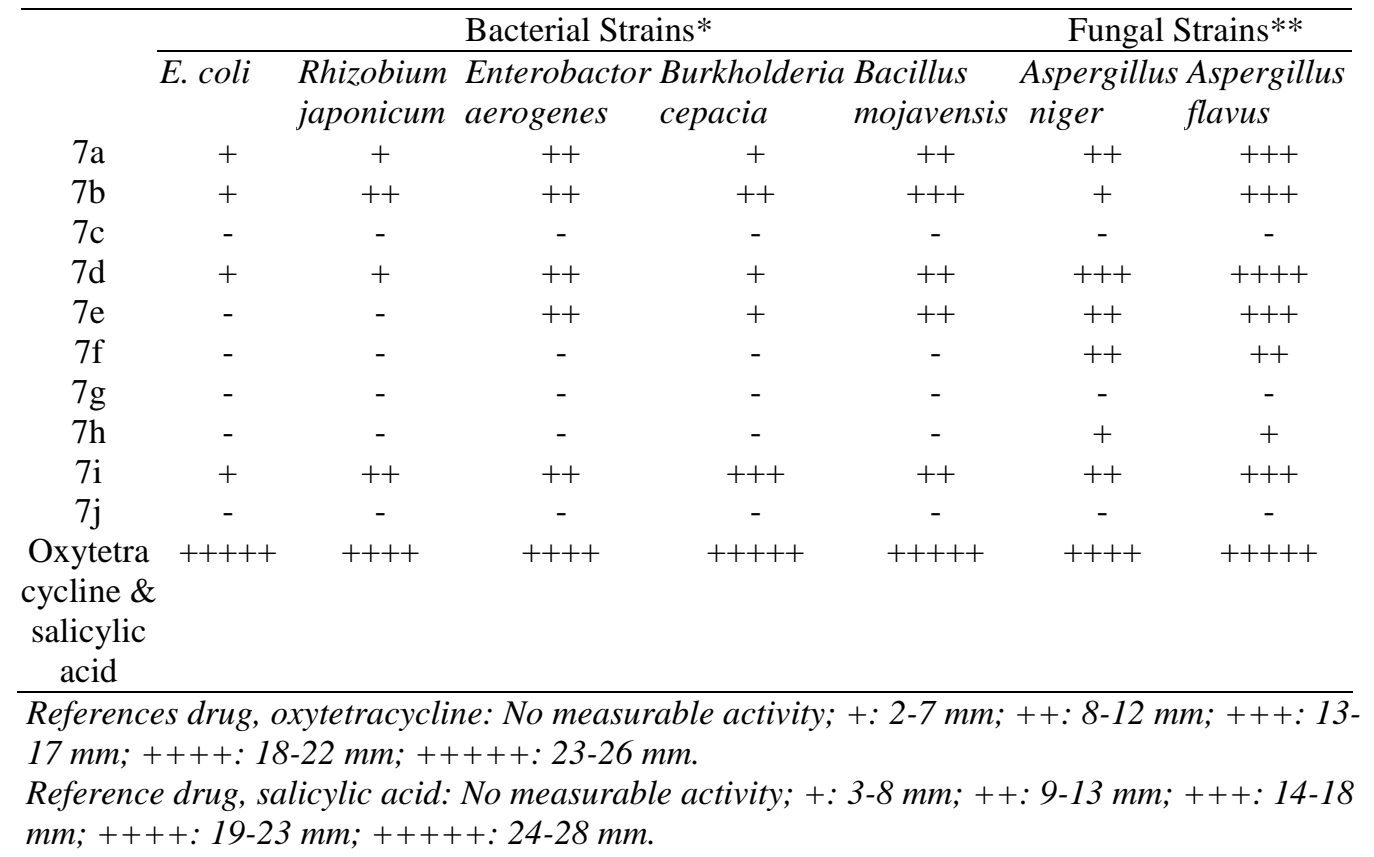

\section{Conclusions}

An efficient and eco-friendly dry media synthetic method has been developed for the synthesis of some novel pyrrolo-pyrimidine derivatives from simple precursors. Microwave dry media synthesis is avoids the use of expensive and hazardous chemicals. The conventional reactions took $11-12$ hours with only $72 \%$ yield whereas dry media microwave reactions took 8-9 minutes with $92 \%$ yield for completion. These results clearly prove dry media microwave irradiation method to be one step advance technology in synthetic chemistry. On the top of this the synthetic pyrrolo-pyrimidine derivatives are found active against various fungal and bacterial strains.

\section{Acknowledgements}

The author is thankful to the Department of Chemistry, P.N. Campus, for providing available facilities, Department of Microbiology, Janapriya Multiple Campus, for assisting in the screening of biological activities of the synthesized compounds and University of Delhi, for cooperating in all the analytical and characterization studies. 


\section{References}

1. R. L. Tolman, R. K. Robins and L.D. Townsend, J. Am. Chem. Soc., 1986, 90, 524.

2. O. M. Pedro, M. P. Jose and I. P. Jean, J. Med. Chem., 2006, 1, 223.

3. T. Ongi, T. Kondo and G. Goto, J. Am. Chem. Soc., 1979, 101, 3629.

4. W. Hutzenlaub, R.L. Tolman and R. K. Robins, J. Med. Chem., 1972, 15, 879.

5. C. W. Smith, R. W. Sidwell, R. K. Robins and R. L. Tolman, J. Med. Chem., 1972, 15, 833 .

6. A. D. Mishra, J. Nepal Chem. Soc., 2009, 24, 49.

7. H. J. Roth, K. Eger and H. Jacobi, DOS 2, 818, 676, 27 April 1978, Chem. Abstr.,1980, 92, p. 58818.

8. K. Eger, R. Fruchtmann, H. Hartmann, S. Raddatz and H. J. Roth, DOS DE 3, 145, 287, 14 Nov 1981, Chem. Abstr., 1983, 99, p. 5378e.

9. K. Eger, G. Grieb and S. Spatting, J. Heterocycl. Chem., 1990, 27, 2069.

10. M. Kidwai, P. Misra and K. R. Bhushan, Polyhedron, 1999, 18, 2641.

11. M. P. Lamontagne and D. C. Smith, J. Heterocycl. Chem., 1983, 20, 295.

12. M. L. Quijano, M. Nogueras and A. Sanchez, J. Heterocycl. Chem., 1990, 27, 1079.

13. H. J. Roth and K. Eger, Arch. Pharm., 1975, 308, 179.

14. J. R. Ross, L. C. Vishwakarma and J. W. Sowell, J. Heterocycl. Chem., 1987, 24, 661.

15. S. Caddick, Tetrahedron, 1995, 51, 10403.

16. A. Loupy, A. Petit, J. Hamelin, F.T. Boullet and D. Matha, Synthesis, 1998, 12, 138.

17. M. Kidwai and N. Negi, Monatsh Chem., 1997, 128, 85.

18. S. Deshayes, L. Marion, A. Loupy and J. L. Lucha, Tetrahedron Lett., 1999, 55, 10851.

19. R. S. Varma, D. E. Clark, W. H. Sutton and D. A. Lewis, J. Am. Chem. Soc., 1997, 80, 357.

20. M. Kidwai, K. R. Bhushan and P. Kumar, Monatsh Chem., 1997, 128, 1291.

21. R. S. Varma and R. K. Saini, Tetrahedron Lett., 1997, 3, 2623.

22. M. Kidwai and P. Misra, Synth. Commun., 1999, 29, 3237.

23. R. S. Varma, R. Dahiya and S. Kumar, Tetrahedron Lett., 1997, 38, 2039.

24. M. Kidwai and K. R. Bhushan, Chem. Papers, 1999, 53, 114.

25. A. Loupy, P, Pigeon, H. Ramdani and P. Jacqualt, Synth. Commun., 1994, 24, 1159.

26. M. Kidwai, P. Misra, R. Kumar, R. K. Saxena, R. Gupta and S. Brandon, Indian J. Chem., 1998, 129, 961.

27. D. C. Dittmer, Chem. Ind., 1997, 25, 779.

28. H. W. Seeley and P. J. Van Denmark, Microbes in Action, WH Freeman and Co. USA, 1972.

29. F. Karanagh, Analytical Microbiology, Academic Press, New York, 1963.

30. D. Steinhilber, K. Schmidt, K. Eger and H. J. Roth, Pharm. Res., 1986, 3, 271.

31. K. Mogilaih and G. R. Reddy, J. Chem. Res., 2004, 10, 363. 